\title{
New Multifunctional Hunting Landscapes in Denmark
}

Christensen, Andreas Aagaard; Svenningsen, Stig Roar; Lommer, Maria Sofie; Brandt, Jesper

Published in:

Danish Journal of Geography

DOI:

$10.1080 / 00167223.2013 .879762$

Publication date:

2014

Document version

Early version, also known as pre-print

Citation for published version (APA):

Christensen, A. A., Svenningsen, S. R., Lommer, M. S., \& Brandt, J. (2014). New Multifunctional Hunting Landscapes in Denmark. Danish Journal of Geography, 114(1), 25-40.

https://doi.org/10.1080/00167223.2013.879762 
This article was downloaded by: [Copenhagen University Library]

On: 22 November 2014, At: 06:54

Publisher: Routledge

Informa Ltd Registered in England and Wales Registered Number: 1072954 Registered office: Mortimer House, 37-41 Mortimer Street, London W1T 3J H, UK

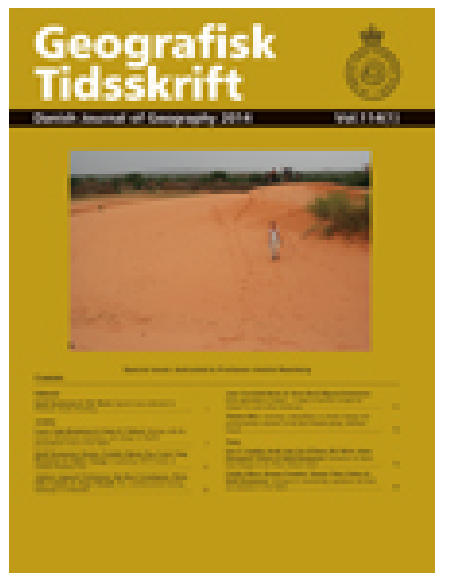

\section{Geografisk Tidsskrift-Danish J ournal of Geography}

Publication details, including instructions for authors and subscription information: http:// www.tandfonline.com/loi/ rdgs20

\section{New multifunctional hunting landscapes in Denmark}

Andreas Aagaard Christensen ${ }^{a}$, Stig Roar Svenningsen ${ }^{\text {bd }}$, Maria Sofie Lommer ${ }^{c} \&$ J esper Brandt $^{d}$

a Department of Geoscience and Natural Resource Management, University of Copenhagen, Frederiksberg DK-1958, Denmark

${ }^{\mathrm{b}}$ National Collections Department, The Royal Library, Copenhagen DK-1016, Denmark

${ }^{c}$ Copenhagen Open Sixth Form College, Valby DK-2500, Denmark

${ }^{d}$ Department of Environmental, Social and Spatial Change, Roskilde University, Roskilde DK-4000, Denmark

Published online: 07 Feb 2014.

To cite this article: Andreas Aagaard Christensen, Stig Roar Svenningsen, Maria Sofie Lommer \& J esper Brandt (2014) New multifunctional hunting landscapes in Denmark, Geografisk Tidsskrift-Danish J ournal of Geography, 114:1, 25-40, DOI: $10.1080 / 00167223.2013 .879762$

To link to this article: http:// dx. doi.org/ 10.1080/00167223.2013.879762

\section{PLEASE SCROLL DOWN FOR ARTICLE}

Taylor \& Francis makes every effort to ensure the accuracy of all the information (the "Content") contained in the publications on our platform. However, Taylor \& Francis, our agents, and our licensors make no representations or warranties whatsoever as to the accuracy, completeness, or suitability for any purpose of the Content. Any opinions and views expressed in this publication are the opinions and views of the authors, and are not the views of or endorsed by Taylor \& Francis. The accuracy of the Content should not be relied upon and should be independently verified with primary sources of information. Taylor and Francis shall not be liable for any losses, actions, claims, proceedings, demands, costs, expenses, damages, and other liabilities whatsoever or howsoever caused arising directly or indirectly in connection with, in relation to or arising out of the use of the Content.

This article may be used for research, teaching, and private study purposes. Any substantial or systematic reproduction, redistribution, reselling, loan, sub-licensing, systematic supply, or distribution in any form to anyone is expressly forbidden. Terms \& Conditions of access and use can be found at http:// www.tandfonline.com/page/terms-and-conditions 


\title{
New multifunctional hunting landscapes in Denmark
}

\author{
Andreas Aagaard Christensen ${ }^{\mathrm{a} *}$, Stig Roar Svenningsen ${ }^{\mathrm{b}, \mathrm{d}}$, Maria Sofie Lommer ${ }^{\mathrm{c}}$ and Jesper Brandt ${ }^{\mathrm{d}}$ \\ ${ }^{a}$ Department of Geoscience and Natural Resource Management, University of Copenhagen, Frederiksberg DK-1958, Denmark; \\ ${ }^{b}$ National Collections Department, The Royal Library, Copenhagen DK-1016, Denmark; ${ }^{c}$ Copenhagen Open Sixth Form College, \\ Valby DK-2500, Denmark; 'Department of Environmental, Social and Spatial Change, Roskilde University, Roskilde DK-4000, \\ Denmark
}

(Received 14 August 2013; accepted 16 December 2013)

\begin{abstract}
Between 1992 and 2008 subsidization of mandatory set aside land under the EU Common Agricultural Policy (CAP) gave rise to the establishment of a characteristic type of multifunctional hunting landscapes in Denmark, primarily located on fallow land in tilled valley bottoms. A national survey of these landscapes in 2006 has been carried out and 1061 hunting areas have been identified nationwide. Subsidies relating to set aside land acted as a supplementary type of income, which supported the development of multifunctional land use on marginal soils where the income from hunting and subsidies in combination was a viable alternative to monofunctional rotational agriculture. Hunting landscapes developed as the consequence of landscape management strategies designed to comply with the requirements of the CAP while improving habitat conditions for wildlife and increasing income from hunting rental activities. Forty-seven percent of the hunting landscapes in 2006 were in rotational production in 2010 while $19 \%$ were used for other agricultural purposes and 34\% were taken out of the subsidy regime and removed from the general agricultural register. In 2012, a total of 431 such areas $-41 \%$ of the areas identified in 2006 - were still used for hunting. The number and geographical distribution of the hunting landscapes seems closely related to the potential average hunting rent, the level of urbanisation and the occurrence of manorial estates with traditions for multifunctional land use as part of their economic strategy. Implications for the ongoing discussion on land use policy concerning land sharing vs. land sparing is discussed.
\end{abstract}

Keywords: land use; land cover; countryside hunting; EU set aside scheme; land sharing; land sparing

\section{Introduction}

In Danish agricultural geography, there has been a long tradition for broad historical studies of land use changes based on interpretation of time series of topographical maps (Jensen \& Jensen, 1977; Jensen \& Reenberg, 1980; Kristensen et al., 2009). Besides the notorious interpretational problems related to the ever-changing military functional content of the legends of these maps, the often abrupt and periodically rapid land use changes have represented a methodological weakness of this type of interpretation. Nevertheless, historical land use studies have proved to be indispensable in the endeavour to improve contemporary directions in land systems research. In an editorial on Handling complex series of natural and socio-economic processes, Reenberg stressed the prominent challenge of "the temporal complexity of land systems, which calls for conceptual models that go beyond 'history matters' and take path dependency and adaptive cycles into account" (Reenberg, 2009). This paper follows up on this request.

Hunting of wild game as a method of generating income or livelihood and as a recreational activity is widespread in most parts of the world and is an integral part of the use of most western cultural landscapes. In
Denmark where the right to hunt is directly linked to land ownership (Primdahl et al., 2012), hunting is generally performed either by land owners as a recreational activity, or by individuals and organizations who rent the land on long leases in order to conduct recreational hunting (Hansen, 2000). Individuals and organizations who rent land for hunting generally assume responsibility for some aspects of the management of the rented land in order to secure efficient gamekeeping, or they expect the owners to provide such landscape management services as part of the rental agreement. These activities primarily involve the creation and effective management of small biotopes in the landscape such as plantings and hunting depots, living hedges, watering holes, earthen dikes, field divides, streams and brooks. The benefit of effective landscape management practices performed by hunters for hunting on rented land is reflected in the rental price paid to the land owner, wherefore long-term rental leases are generally more expensive per year than short-term leases (Lundhede et al., 2009). Gamekeeping activities like these are a prerequisite for hunting in Denmark, because the intensively used Danish landscapes are dominated by agricultural production surfaces between which only a limited

\footnotetext{
*Corresponding author. Email: anaach@life.ku.dk
} 
amount of space is left for other types of surface cover, including small biotopes needed by the species of deer and gallinaceous birds which are the primary game animals (Bloch-Pedersen et al., 2006; Jensen \& Reenberg, 1980).

In the open countryside small biotopes are generally placed in accordance with the framework of field boundaries, woodlots and abandoned mineral extraction sites defined by the historically developed spatial pattern of the agricultural land use systems. While small biotopes have generally decreased drastically both in numbers and area from 1950 to 1986, there has in average - but with large regional and local variations - been a noticeable increase in the amount of small woodlots and water features and the length of living hedges since the mid1980s, a development which has been directly linked to hunting activities (Brandt et al., 1994, 2001). These new small biotopes are to a large degree placed in the traditional pattern along field divides and property divides or in connection with existing historical marl pits and similar landscape features, with a minimum of interference with the agricultural space of action. This subordination of vegetated and wet areas to the patterning of agriculture, in combination with a legal framework linking hunting to land ownership, has meant that hunting rental in the open land in Denmark has developed as a secondary source of income for farmers, who generally derive their primary income from either a combination of agriculture and agricultural subsidies (professional farmers) or from urban employment (hobby farmers) (Primdahl et al., 2012).

As a consequence of these circumstances, countryside hunting has been performed from along linear biotopes and across agricultural fields with rotational crops or permanent grass. In practical terms, this means that farmers have been able to collect income for the same area from both agricultural production, agricultural subsidies and hunting rental, because hunting has been performed in accordance with agricultural principles for functional agricultural optimization and not vice versa. This type of multifunctionality, in which subsidies from the EU Common Agricultural Policy (CAP) plays an important part, has made it economically reasonable for farmers to continue agricultural production (and avoid field abandonment) in the many riverbeds and bog areas which cut across Denmark, where agriculture is least effective and where small biotopes are relatively more numerous. The CAP subsidies have supported the existing land use system by balancing the income linked to agriculture with the income possible through intensified hunting or other recreational activities, making it more rational to keep up agricultural production. This has been further underpinned by the risk imposed by the third article of the Danish nature protection act, which since 1992 has demanded a 'general conservation' of habitats located on agricultural land if the habitats are either covered by more than 100 sq. $m$ of permanent water, or if more than a quarter hectare have been allowed to assume a natural or semi-natural vegetation cover as detailed in the list of protected habitat types (Brandt, 1994; Ministry of the Environment, 2013). The list of habitat types eligible for conservation includes types of natural and semi-natural grassland along with a number of wetland habitat types which typically develop through succession on abandoned and undrained fields - effectively making it risky for farmers to invest in nature seen from a purely agricultural point of view.

Between 1992 and 2008, however, the conditions for decision-making described above were different due to the existence of the fallow land scheme which made it possible for farmers to let land lay fallow and build up semi-natural plant societies on agricultural land, while receiving subsidies and at the same time preventing article three conservation of the land. Subsidy regimes for set aside land had long been in place in Denmark with $0.3 \%$ of the agricultural area $(9.485 \mathrm{ha})$ laid fallow in 1991, but with the MacSherry reform of 1992 subsidies were reoriented to support a less productive agricultural sector and set asides became mandatory (Mogensen et al., 1997; Kristensen \& Pedersen, 2008). For each following year until 2008, an annually fluctuating percentage of the total agricultural area of each farm was laid fallow as a prerequisite for receiving EU subsidies (DJF et al., 2007a, 2007b). This combination of regulations and options presented to the farmers made it possible for farmers to shift into indirectly "subsidized" hunting retail activities for a brief period of time until the fallow land scheme was abandoned in 2007, with effects taking place in the growing season of 2008 (Kristensen \& Pedersen, 2008). At that time approximately $3 \%$ of the agricultural land in Denmark was converted from set asides to production and the country lost 80.000 ha of semi-natural surface cover (Levin \& Jepsen, 2010). Many of the most stabile of these areas, which had been set aside longest and thus had developed the richest flora and fauna, were situated in wetland areas along river valleys with organic soils. The loss of these high nature value set asides had implications at a national scale both for the level of biodiversity protection possible in the landscape and for local aquatic environments, because the nitrogen filtering functions performed by the fallow organic soils were damaged or lost and because more land became available for treatment with nitrous and phosphorous fertilizers (DJF et al., 2007a, 2007b). These implications raised an intensive public debate in the fall of 2008 when the results of the policy change became clear (Bertelsen et al., 2008).

The hypothesis of the study reported in this article was that the special conditions for land management present since 1992 would have made farmers able to 
develop novel multifunctional land use strategies on the fallow lands in competition with traditional agricultural land use strategies, due to the provision of set aside subsidies. The possible development of a hunting economy based on the ecological resources present on the fallow lands was hypothesized to indicate the extent to which farmers are willing to shift from agricultural production to nature conservation activities on parts of their property, given conditions that would make such decision behaviour economically feasible. The removal of the fallow land scheme after 2008 has provided an additional opportunity to test this hypothesis.

\subsection{Multi and monofunctional approaches to landscape management}

An increasing pressure on land use and its planning and regulation has emerged globally by a combination of rapidly growing markets for food and energy crops and a growing demand for land use adaptation to reduce agricultural impacts on biodiversity, to prepare for an expected required climate mitigation and to fulfil the need for a number of future land demanding activities that develop in the wake of increased wealth, spare time, spatial mobility and improved infrastructure. This has given rise to an international controversy as to whether these challenges should be met by 'land sparing' where a conventional spatially concentrated intensified agriculture gives room outside these areas for other types of land use, including strictly protected natural areas, or by 'land sharing' - where agricultural production might intensify, but in a wildlife-friendly and explicitly environmentally adapted way, giving space for other types of land use functions through an integrated multifunctional adaptation strategy (Phalan et al., 2011). Land sparing can be considered a follow-up of a 'segregation policy' traditionally implemented in nature conservancy in 'the new world' (primarily in USA, Australia and New Zealand but also in many developing countries), whereas land sharing has in general been preferred and defended in Europe, dominated by old cultural landscapes, often with a rich historically conditioned biodiversity (Plieninger et al., 2006; Tscharntke et al., 2012; Antrop et al., 2013).

The discussion on land sparing vs. land sharing is closely related to the historical abandonment of common use and ownership regimes during the development of capitalism, since this implied a functional segregation of land use on a landscape scale. Although many conflicts between different landscape functions for a rather long period have been solved through land sparing/functional segregation, the benefit from use of land is increasingly optimized when different uses are integrated, due to increasing land scarcity, population pressure and a growing demand for new products, services and common reg- ulations related to recreational amenities, biodiversity, aesthetics, groundwater and climate regulation (Vreeker et al., 2004; Hodge, 2007; Vejre et al., 2012). Countryside hunting is an example of a land use which depends directly on such integrative and multifunctional modes of landscape management. This is due to two characteristics pertaining to the wild game such as deer and galinaceous birds which is the key resource for a hunting economy: (1) The game animals depend on vegetation patches and corridors that do not support agricultural production as such, but are located within agricultural landscapes; and (2) The game animals exist as a common resource in an individualized, enclosed landscape - roaming across the landscape and transcending proprietary and (mono)functional boundaries.

Since the Second World War, Danish landscapes have become increasingly adapted to monofunctional agricultural production, and this has made it increasingly difficult to conserve game populations in other ways than by finding methods to cater for specific species in ways which do not interfere with agriculture. This has been clearly reflected in the populations of wild game available for hunting. Formerly widespread game species such as Brown hare (Lepus europaeus) and Gray partridge (Perdix perdix) have diminished since the 1950s due to rapidly decreasing amounts of multifunctional fallow land and semi-natural grassland and reduced amounts of weed plants in- and outside rotational production surfaces. At the same time there has been an explosive increase in populations of Roe deer (Capreolus capreolus), a species which thrives on the type of herbaceous and broadleaf vegetation types which farmers have been able to plant as linear landscape features between fields - i.e. without diminishing the area available for monofunctional agricultural production (Olesen et al., 2002; Asferg et al., 2009).

The hunting landscapes which are identified and discussed in this article can be interpreted as a return to or continuation of the formerly widespread practice of multifunctional landscape management, where gamekeeping was integrated spatially and temporally with agricultural production along with numerous other functions. As such, it may represent a locally adapted solution to the problem addressed by the land sharing/land sparing debate: the need for land use combinations which are mutually supportive, in landscapes dominated by an increasing competition for space.

\subsection{Multifunctional Danish agricultural landscapes and hunting}

It is difficult with any precision to ascertain the relationship between hunting activities and the landscape changes which have taken place in Denmark in recent history. This is due to the fact that national-scale land 
use monitoring efforts ceased after 2001 and that most of the studies which deal with hunting-related questions are based on non-spatial methods such as questionnaires, making it difficult to determine the relationship between observed landscape changes and hunting. The limited evidence which is available does however suggests that there is a significantly understudied relationship between hunting and landscape management. One of the clearest results indicating this was published by Brandt et al. (1994), concluding that more than two-thirds of the increase in number and length of small biotopes such as hedges, ponds and plantings that took place in the 1980s can be associated directly with gamekeeping and hunting activities (Brandt et al., 1994). Recent case studies from Northern Jutland also suggest a continued growth in the number and area of small biotopes from 2006 to 2011, primarily associated with recreational land use functions on properties owned by hobby farmers and pensioners (Christensen et al., 2012a, 2012b). On land owned by full-time and part-time farmers the trend is less significant in the cases studied, and it is likely that the continued increase in the number and area of small biotopes on land owned by hobby farmers is balanced on a national scale by a decrease on land held by full-time farmers focusing on productivist landscape management (see Wilson (2001) for a discussion of such landscape management strategies). This may be evidence of a new trend where amenity values and hunting interests coincide or it may be an expression of underlying shifts in the type of interest motivating the creation of small biotopes in Danish landscapes, associated with the continued urbanization and recreationalization of the countryside. But further interview data are needed to link the observed changes directly with land use functions, and it is unknown whether the same trend characterizes landscape management practices in Denmark as whole. The available data does suggest, however, that hunting as a land use practice has played an important role in motivating the creation of small biotopes in the 1980s, and the case study data from Northern Jutland show than only very few of the existing small biotopes were removed after 2006 (Christensen et al., 2012a, 2012b), implying that the small biotopes planted or otherwise created in the 1980s may still be appreciated for hunting purposes, or that they have attained other use values subsequently and thus still are considered a resource to the land owners. A smaller interview-based case study from 2011 conducted in two parishes on Zealand corroborates this interpretation, demonstrating a strong link between hunting activities and increases in the amount and extent of small biotopes (Pedersen, 2011). In addition to this, a national-scale interview survey from 1999 suggests that Danish hunters in general, when hunting in the open countryside, prefer to hunt on extensively used land without rotational crops (Hansen, 2000), and that 79\% use one or more days a year on improving the area in which they hunt - implying that the land and its vegetation are considered important by hunters. Hunters exhibit a set of preferences for certain landscape qualities associated with high levels of vegetation cover, and a survey from 2006 to 2007 has shown that these preferences are reflected directly in the price paid by hunters for renting hunting rights in the Danish countryside (Lundhede et al., 2009).

While most of these studies corroborate and expand on the hypothesis of a close relationship between hunting and landscape management, they pose a number of unanswered questions regarding the geographical location and distribution of landscapes used for hunting, or with potential for a hunting economy. The present article is, in part, an attempt to fill this knowledge gap, by providing a national-scale map of areas where hunting has taken place in ways which significantly altered the local landscape and led to the development of multifunctional land use systems able to compete for space with productivist agriculture.

\subsection{The expanding Danish hunting economy: strategic landscape management for hunting}

\subsubsection{The expanding hunting economy}

Apart from its apparent impact on landscape management practices, hunting is also significant in terms of rural development. A questionnaire study performed in 1999 has shown that members of the Danish hunting association spent an average of 12.000 DKK a year on hunting-related expenditures (on top of fees paid for hunting licenses), out of which the largest single item was rental fees to gain access to hunting areas (Hansen, 2000). This estimate of the average annual investment incurred by the then 88.000 members of the Danish Hunting association suggest that the total market for hunting-related goods and services with rental payments forming the bulk - can be hypothesized to average approximately one billion Danish crowns a year - a figure which may be grossly underestimated given that 83.000 Danish hunters who are not part of the hunting association are not included in the calculation. Hunting thus constitutes an important biological economy in the countryside and work as an income source for land owners, who through hunting rental can profit from improving the conditions for wildlife and from improving natural habitats and aesthetic landscape qualities. Given that only approximately $24 \%$ of hunters use hunting areas owned personally or by relatives and $60 \%$ of hunters live in houses which do not form part of an agricultural holding (Hansen, 2000), hunting can be conceived as a link between urban and rural economies, where hunting acts as an income source and as a driver for planting activities and other landscape management practices. This means that hunting represents a way for land owners to "harvest" 
local and otherwise intangible amenity values through hunting rental - thus converting aesthetic and ecological qualities to economic currency.

\subsubsection{The hunters and their landscape preferences}

The broad countryside recreational nature of hunting is emphasized by the fact that two-thirds of Danish hunters shoot less than one-fifth of the total game each year (Asferg, 1991). Thus, there is a large group of hunters, for whom their leisure time activity is a way of outdoor recreation with only limited emphasis on the hunting, and a minor, very active group of hunters, probably focusing on a high availability of game. Studies from Southern Sweden support this interpretation (Persson, 1981). The very active hunters are selective in their choice of hunting area, placing great demand on game density, core areas, habitat structure and possibilities of game management. Hunting rent can be extremely high where these conditions can be fulfilled, such as on many of the manorial estates. But also in the general farmland, hunting rent seems to depend on the amount and structure of habitats. In areas with a very low coverage of biotopes even a small increase in biotopes might improve the quality for hunting considerably, while in areas with a high amount of tree cover the increase in hunting rent when planting new biotopes is less significant and perhaps even negative, due to the elementary importance of open space between habitat patches for countryside hunting activities. The coverage of small biotopes in Danish agricultural landscapes is quite low and varies between 1.5 and 6.0\% (Brandt, 1994), meaning that there is likely to be a much higher potential for increasing hunting rent through small increases in the percentage of small biotopes than previously assumed. This was an important economic reason behind the stabilization of small biotopes and especially the increase in game-oriented habitats from the middle of the 1980s. Large regional variations exist however, and the data suggest that hunting rents fall with the distance to the main population centres. However, hunting on the manorial estates and in large forests and such high-quality hunting grounds is likely to be a separate economy, functioning independently of the more widespread "game market". The landscape impact of hunting is thus reflected in the habitat density and structure of the countryside.

Although strategies for managing landscapes for hunting purposes are varied and numerous, especially three landscape management strategies have become important in Denmark:

(1) A multifunctional largeholder landscape management strategy which is prevalent on the Danish manorial estates, designed to extract profit from the multifunctional land use synergies of a diverse landscape setting, which is planned and operated by a single agent (Brandt, 2012; Christensen et al., 2011).

(2) A monofunctional largeholder agricultural strategy, focusing on specialized production where hunting may be present, but is basically subordinated to the main productivistic strategy focusing on land in rotation.

(3) A smallholder landscape management strategy, where gamekeeping takes place on small plots located along river valleys, forest edges, coastlines or similar large-scale ecological corridors, and where gamekeeping consists in attracting and supporting relatively transient populations of deer and birds which travel along or otherwise depend upon these corridors.

\subsubsection{Largeholder hunting based on long-term strategic landscape management}

Already in the economic landscape planning of the Enlightenment, intensification of agricultural land use was combined with a parallel planning of often commercial countryside hunting activities, typically located on manorial estates (Hirsch, 1985). In Denmark as elsewhere, such hunting activites have been an important aspect of the multifunctional land use of the manorial estates, which still stand out from other largeholder producers by being able to combine agriculture with hunting, forestry, rental housing and various recreational activities, thus profiting from a diversity of landscape resources. Manorial estates cover approximately $8.5 \%$ of the Danish countryside, mostly concentrated in the eastern part of the country (Christensen et al., 2011; Pedersen, 1980). Although their land base has been characterized by large fields and large-scale mosaic structures compared to the more fine-grained landscape structure which is the general pattern in Denmark, the manorial landscapes are also characterized by the large numbers of biotopes with a high nature quality. Here hunting is a central commercial activity, and hunting revenue on such estates often amounts to between onefourth and one-half of the total income, thus playing an important role in the overall landscape management strategy of both the forests and the agricultural land of the estates. In general, the Manorial estate of today comprises a stable, well connected single domain of land with an average size of more than 500 ha, optimizing a multifunctional land use strategy adapted to the local landscape conditions.

Danish largeholder operations in general stand in stark contrast to the manorial estates in terms of the landscape management strategies employed. As a result of the general structural development towards still larger 
and specialized agricultural holdings, a large part of the agricultural land in Denmark is today occupied by large, but mostly very spatially fragmented holdings, focusing on specialized intensive production, for example within pig farming. On these specialized 'productivist' largeholder operations, the optimization of rotational land use is in focus, with a rather limited effort to promote supplementary types of land use through potential local ecosystem services such as hunting (Wilson, 2001).

\subsubsection{Smallholder hunting and the common resource of small biotopes in the Danish countryside}

Most hunting has traditionally taken place in the open countryside in Denmark, and large efforts have been invested in improving the conditions for game by increasing the amount of permanent vegetation. Since the nineteenth century, different public support schemes relevant for hunting have been carried out in Danish agricultural landscapes, which from the 1930s have been financed partly through hunting licence fees (Primdahl et al., 2012; Sørensen, 1983). But despite these efforts, continued structural changes in the agricultural sector have meant that the total amount of small biotopes in the landscape have been falling until the 1980s. The demographic basis for the countryside hunters has traditionally been the farmers. But, during the rapid agricultural structural development from 1959 to 1994 this working force contracted from 284.000 to 93.000 (Hedegaard et al., 1995). In 2010, 80.500 persons were employed on 42.000 holdings in Denmark (Statistics Denmark, 2012). The number of registered hunters has, however, remained fairly stable around 170.000 persons, indicating a shift in the composition of hunters toward a majority of hunters employed outside the primary sector who borrow or rent land for hunting purposes, often based on former local agricultural relations (see also Hansen (2000) and Primdahl et al., (2012)).

\subsection{Research questions}

The present article presents the results of a national survey of the use of fallow land for hunting near the end of the fallow land scheme in 2008. The study is based on fieldwork at a survey area on the island of Zealand conducted in 2008 and 2009 and an explorative mapping of the phenomena at a national scale, using orthophotos recorded in 2006, based on which lands with visible signs of hunting activity were mapped. In this context, we asked the following research questions:

(1) To what extent do multifunctional hunting landscapes constitute a national phenomenon and how are they distributed spatially?
(2) To what degree did the subsidization and creation of set aside fields which took place in the period up until 2008 coincide temporally and spatially with the development of multifunctional hunting landscapes in Denmark?

(3) To what degree do the new multifunctional hunting landscape represent a alternative land use strategy to traditional segregational approaches to landscape management in agriculturally marginal rural areas?

\section{Methods and materials}

The relationship between land cover and land use in rural areas dominated by landscape management practices focused on hunting rental has been studied on two different scales using a combination of case study and survey approaches. Links between hunting activities, other landscape management strategies and changes in physical land cover structure were investigated at a local scale using a case study approach. This led to the establishment of a knowledge base linking certain types of physical landscape structure to specific land use practices. Based on these experiences, a national-scale explorative survey was initiated with the purpose of identifying the extent of similar land cover structures in the rest of Denmark, hypothesized to be evidence of similar hunting and land management practices. The results of the survey, which was based on on-screen analysis of orthorectified aerial photography, were later validated through a number of field visits to substantiate the qualitatively based inference between land cover and land use.

\subsection{The case study in Amosen river valley 2008}

In the fall of 2008, a $4 \mathrm{~km}^{2}$ large survey area located in the Aamosen wetlands on the Island of Zealand in eastern Denmark was mapped and the land owners were interviewed. The survey area was selected because it fits the characteristics hypothesized to make the establishment of a countryside hunting economy a viable choice to local farmers. The survey area is characterized by its location in a river valley with organic soils, forming an ecological corridor of regional importance. It contains a relatively large amount of small biotopes distributed mostly along field divides and high levels of ground water make agriculture a less-effective land use strategy in the area when compared to neighbouring areas outside the river valley. Precise land use and land cover maps were available for the area due to its inclusion in the national small biotope monitoring system between 1981 and 1996 (Brandt et al., 2001). The maps from 1996 were updated in situ during a four-week field campaign 
where $96 \%$ of the fields and vegetation patches of the area was visited and remapped. The crop type and land use characteristics of each field were recorded, and the characteristics of the surface cover was recorded. A classification scheme was adapted from the inventory of crop types and biotope types developed for the national small biotope monitoring system (Brandt et al., 1994). Special attention was paid to the set aside fields of the area $(n=$ 6) and set aside fields were mapped and described using the classification scheme also used for the biotopes. Separate maps were developed for each set aside field detailing the spatial structure of vegetated and open areas on the fallow land, originating from a combination of natural succession and non-agricultural land use related to hunting activity. The land owners of the area $(n=10)$ were interviewed and their land use practices were mapped using a spatially explicit interview method, in order to verify the relationship between hunting activity and observed surface cover structures on the fallow land. A distinctive linear spatial pattern consisting of a combination of strips of anthropogenic (mowed) grass cover and natural shrubbish grassland was found to characterize the set aside fields used for hunting. This land cover structure, which was found to be associated with landscape management activities related directly to hunting, was also easily identifiable on orthophotos, and this made it possible to perform a national-scale mapping of similarly structured hunting areas as described below (Figures 1 and 2).
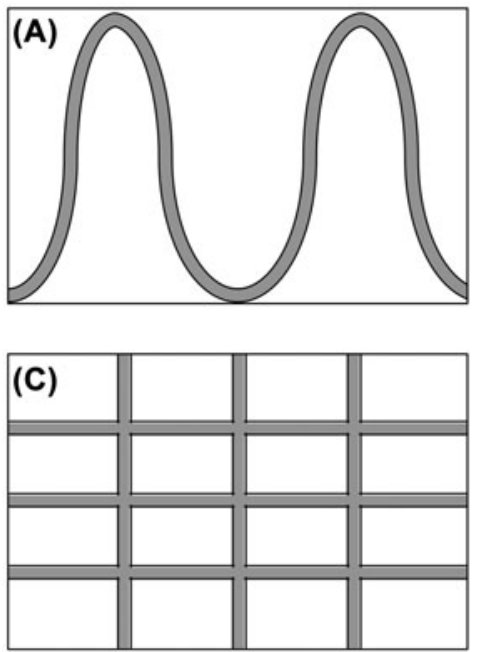

\subsection{The national-scale orthophoto survey}

Based on the results of the case study in combination with additional field visits and orthophoto analysis of other areas on the island of Zealand, a national-scale survey was conducted, designed to identify areas with a vegetation structure similar to the structure known to reflect a landscape management practice centred on hunting. The survey was initially conducted using aerial images from 2006 available freely through the Google Earth application but was later checked in a GIS environment employing a series of orthorectified aerial photographs recorded by a private contractor for the Danish National Survey and Cadastre Agency in the summer of 2006. The imagery was divided up into $2.7 \mathrm{~km}$ wide lanes from north to south and each lane of imagery was screened manually at a scale of approximately 1:8000. The screening of the imagery was intended to provide an approximation of the total number of fields with distinctive hunting-related surface cover in Denmark. Danish landscapes are generally divided up into agricultural and pastoral fields, which are delineated from each other by narrow strips of grass and herbaceous vegetations, by fences, woodlots and hedgerows or by ditches or watercourses. All areas bordered by such linear landscape elements visible on the imagery were considered to be individual fields, and all individual fields with a surface cover similar in structure to the hunting-related surface cover identified in situ during fieldwork were mapped (Figure 1). The mapping procedure was designed to
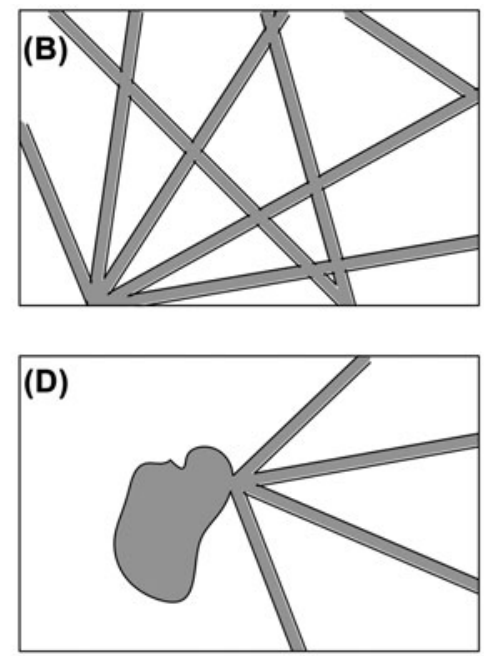

Figure 1. A conceptual sketch of four variations in land cover structure characteristic of the hunting areas identified during fieldwork and pilot surveys in 2008. Lanes of cleared land covered by young grasses and herbs (grey) intersect the semi-natural shrub and grassland cover of the area in general (background). This constitutes a surface cover which is suitable as a foraging ground for and attracts fowl and deer, while providing hunters with easy access and overview. It was these spatial structures, which were found to be evidence of a landscape management strategy focused on hunting, that were later mapped at a national scale using orthophotos to identify hunting areas elsewhere. The four types are: (A) snake-shaped series of curved lanes, typically found on narrow strips adjoining a stream used to optimize hunting on elongated narrow fields, (B) constellations of lanes servicing several shooting towers or hochsitz with overlapping lines of sight, (C) rectangular patterns of lanes used to hunt from positions on the ground and (D) star-shaped sets of lanes extending from a single shooting tower or hochsitz located at the edge of a small biotope. 

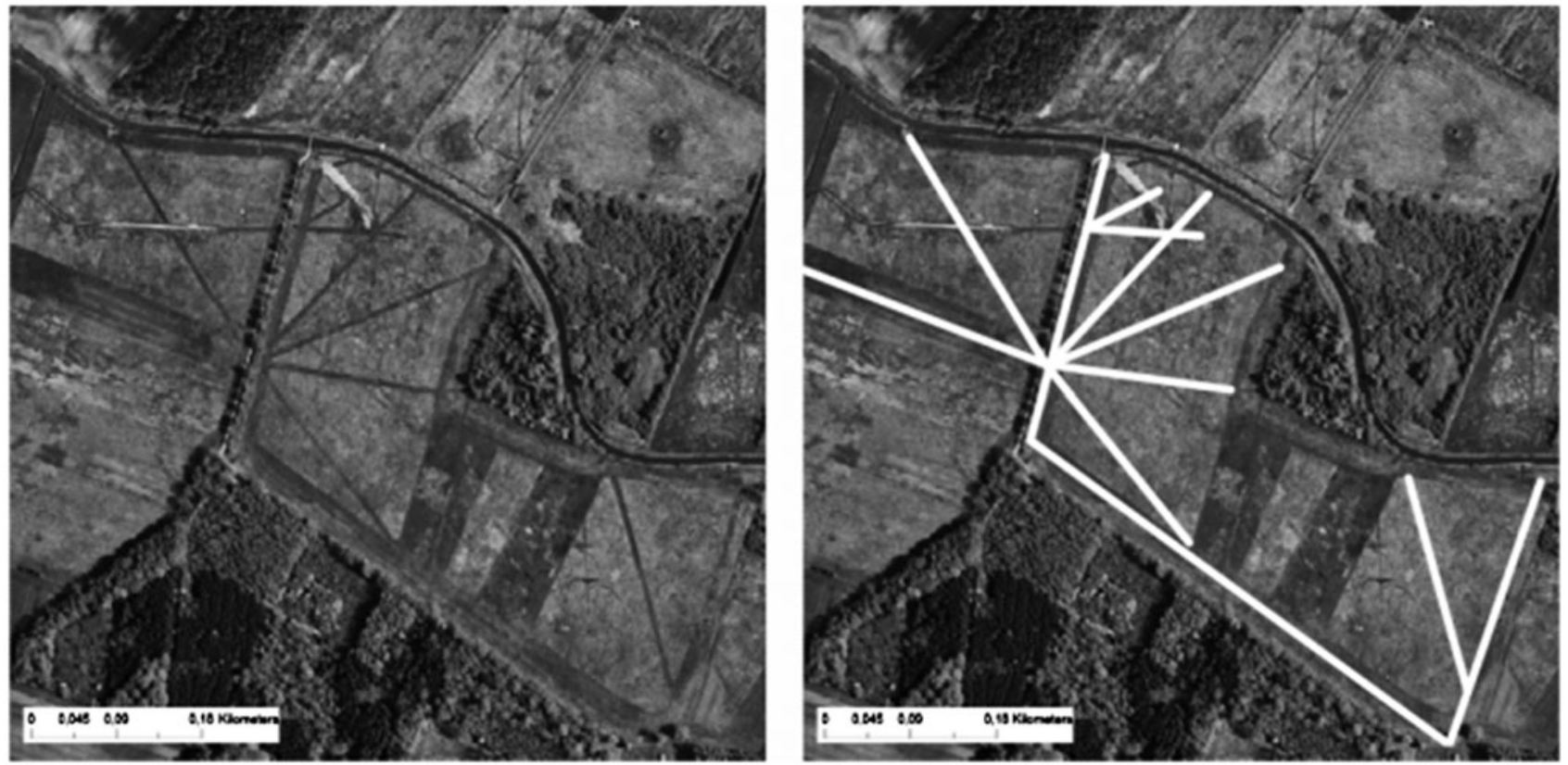

Figure 2. A sample of orthophotographs from 2006 illustrating the visual characteristics of a typical hunting landscape found in the case area. Shooting lanes with trimmed grass cover are highlighted on the right hand image. Shooting towers and hochsitz are situated at the points of intersection between shooting lanes, which contain attractive grazing opportunities for gallinaceous birds and deer. Source data: Cowi DDOland 2006.

estimate the number and location (central point) of single hunting areas only, wherefore the acreage of the fields on which the hunting areas were located was not included in the mapping procedure. In cases where a hunting area identified in the imagery was found to extend across field boundaries, it was necessary to interpret from the imagery whether the hunting area was in fact a single instance of the structure we were looking to identify, or whether it was a case of two or several of such structures existing individually beside each other on adjoining fields. In such cases, the structure of the hunting area (as illustrated in Figure 1) was considered an indicator of whether a single or several hunting areas existed: (1) In cases where the structure of the hunting area extended across fields divides, it was mapped as a single data point, (2) In cases where adjoining fields were found to contain several unattached structures which were found to fit the structural types illustrated in Figure 1 individually, but not when seen as a whole, two or several data points were mapped. This was done in order to assure that the data-set would represent the number of functionally separate hunting areas as precisely as possible.

A total of 1061 hunting areas were identified. In order to determine whether the remote classification was correct, $7.2 \% \quad(n=76)$ of the total number of hunting areas identified were visited in 2008 and in the spring of 2009. Due to practical concerns the samples which were visited were selected, so that it was possible to reach them from Copenhagen by car during a number of oneday field trips. The 76 field visits were sampled to achieve as wide a geographical distribution as possible, within the geographical region available for field checks given the restraint of our location in Copenhagen. The existence of hunting landscapes in the areas visited was determined in situ based on the the presence of shooting lanes (as illustrated in Figure 1) and hunting-related infrastructure such as shooting towers and fodder barrels related functionally to the shooting lanes.The classification as hunting landscapes was found to be correct in all the cases visited.

The age and permanence of the identified hunting areas was determined by overlaying and comparing the 2006 map (which was the product of the orthophoto survey) with orthophotos from 2012, 2008, 2004, 2002, 1999 and 1995 (Table 1).

\section{Results}

\subsection{The structure and function of hunting-related land cover in the case area}

Results from the field survey show that hunting was practised intensively on all parts of the $2 \times 2 \mathrm{~km}$ survey area visited in 2008. Signs of gamekeeping activity such as strips of planted fodder crops (maize), salt licks for deer and fodder barrels for pheasants were found in all 
Table 1. Data-sets used for the national-scale survey of hunting areas. The data-set from 2006 was used to produce a map of hunting areas at that time, which was then compared with the remaining data-sets to establish the approximate duration of the identified land cover structures. The spatial resolution of the data has improved over time, and was considerably lower in 1995 than later. However, it was still possible to identify the distinctive patterns of the hunting landscape on the aerial photographs with lower resolution before 2004 .

\begin{tabular}{lcl}
\hline Data-set & Resolution & Time of recording \\
\hline DDOland2012 & $12.5 \mathrm{~cm}$ & May-June 2012 \\
DDOland2008 & $12.5 \mathrm{~cm}$ & May-July 2008 \\
DDOland2006 & $25.0 \mathrm{~cm}$ & May-July 2012 \\
DDOland2004 & $25.0 \mathrm{~cm}$ & June 2004 \\
DDOland2002 & $40.0 \mathrm{~cm}$ & May-August \\
DDOland1999 & $40.0 \mathrm{~cm}$ & May-July \\
DDOland1995 & $80.0 \mathrm{~cm}$ & June-July \\
\hline
\end{tabular}

parts of the area and interviews with the land owners confirmed the presence of a general interest in hunting and hunting rental. A large part of the hunting activity recorded during fieldwork was related to traditional types of hunting, performed from along hedges and river banks shooting at game across rotational cropland. The areas which according to the land owners were used most intensively for hunting were set aside fields which were not in operation with rotational crops, where semi-natural plant societies of large grasses, different species of perennial plants and shrubbery of Grey Willow (Salix Cinerea) and Elder trees (Sambucus Nigra) dominated the surface cover. These areas were rented out to local hunting associations who had assumed responsibility for managing the areas. All of the set aside areas used for hunting were reported by land owners to be included in the fallow land subsidy scheme as of 2008. The land owners were unwilling to disclose the actual amount of income acquired through hunting rental and subsidies, respectively, but reported that the two income sources in combination with each other represented a total income which was able to compete economically with traditional agricultural production on the wet organic soils of the survey area. The land owners also expressed a satisfaction with the semi-natural surface cover on the fallow land, which they considered more beautiful and more suited for outdoor recreation than the former cropland surface which was present before 1992. Recreation, nature conservation, hunting rental and subsidization were found to be the only land use functions associated with the fallow land areas, which suggests that signs of recent landscape management activity on the fallow land relate to one or several of these functions.

The fallow land used for hunting was found to be structured in a very specific pattern. Shooting towers and hochsitz were placed strategically at the vertexes of complex linear systems of narrow, well-trimmed grass-clad shooting lanes, surrounded by high grasses and shrubbery. The result was a surface cover structure which was well suited both for a comfortable hunting experience, and for effective gamekeeping because it combined grass covered open foraging areas needed by birds such as common pheasant (Phasianus Colchicus) and partridge (Perdix Perdix) with excellent nesting opportunities in the shrubbery. The spatial structure of this type of landuse specific vegetation is illustrated in Figure 2, where the grass-covered shooting lanes are highlighted. The system of shooting lanes - which were generally approximately $10-15 \mathrm{~m}$ wide - stand out unmistakably on colour imagery because of the difference in texture and complexion between shrubbery and trimmed grass. A number of variations in the layout of such shooting lanes was identified during fieldwork as is illustrated in the conceptual drawing in Figure 1. The conceptual drawing combined with a number of observations concerning typical colour differences between the vegetation types present (observed during fieldwork) formed the basis of the national-scale survey of imagery which was intended to identify areas with similar surface cover structures as detailed above.

\subsection{Hunting landscapes as a management strategy on marginal soils in the Danish countryside}

Results from the national-scale survey show that in 2006 , a total of 1061 single hunting areas were covered in vegetation similar to the set aside fields of the survey area (Table 2, Figure 3). Results from the field validation procedure conducted in 2008-2009 support the idea that such surface cover is closely related to hunting, given that investments in hunting such as foddering barrels, shooting towers and constructed watering holes were present in all 76 cases. The spatial distribution of the hunting areas is illustrated in Figure 4 below, along with the location of the survey area, the field validated cases, and the pattern of wetlands and organic soils in relation to which the hunting areas are generally located.

The growth in the number of hunting areas from the mid-1990s and the decline after 2007/2008 is shown in Figure 3. Because of the fact that the survey was based on sites identified in 2006, the graph has to be interpreted with some caution. During the historical inventory of the sites identified in 2006, it became clear that although it is a strong tendency that the number of hunting areas rise until 2006 and then decline, there are also unknown number of cases where similar structures appear nearby the abandoned sites in subsequent years. This could indicate that the hunting landscapes, at least to some degree, are moving around and not disappearing as rapidly as first assumed. However, these new sites were not mapped as part of the methodology employed here. Taken together the results support the hypothesized 
Table 2. Results of the on-screen survey of hunting areas identified in 2006. Only 28 of the 1061 hunting areas identified in 2006 were 11 years old or more, but 431 were still in existence in 2012 despite the suspension of the set aside scheme in $2007 / 2008$.

\begin{tabular}{|c|c|c|c|}
\hline Year & $\begin{array}{c}\text { Signs of hunting } \\
\text { In the areas identified in 2006 }\end{array}$ & $\begin{array}{c}\text { No signs of hunting } \\
\text { In the areas identified in 2006 }\end{array}$ & \\
\hline 1995 & 28 & 1033 & \\
1999 & 108 & 953 & \\
2002 & 261 & 800 & \\
2004 & 486 & 575 & \\
2006 & 1061 & 0 & \\
2008 & 789 & 272 & \\
2012 & 431 & 630 & \\
\hline
\end{tabular}

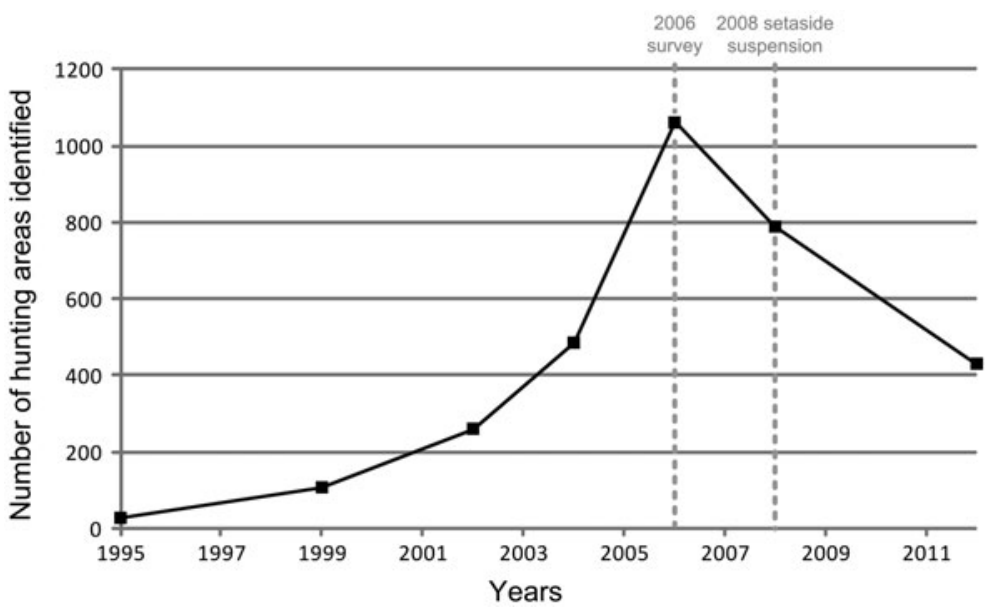

Figure 3. The number of hunting areas identified in 2006, which were also present in the years 1995-2012. The number of areas grew steadily towards a peak in 2006, the year before the suspension of the setaside scheme. Since then the number of areas declined, but a substantial amount (431) survived until at least 2012 despite the change in policy which took place in 2007/2008.

relationship between multifunctional landscape management practices relating to hunting and the set aside policy, which made it mandatory to let land lay fallow in 1992. Since then more farmers have established hunting areas on their land at a gradual pace - especially on marginal and wet soils. Since 2006 they have disappeared at a rapid pace, even though some may have moved to other areas.

Most of the hunting areas are situated in river valleys where conditions for agriculture are relatively poor and $70.6 \%$ of the hunting areas were found to be located within $1 \mathrm{~km}$ from a river, while $77.3 \%$ of the hunting areas were found to be situated on either sandy or organic soils, soil types which constitute only $54.8 \%$ of the Danish land mass (Table 3).

With the exception of the island of Bornholm where bedrock is present at surface level, Danish landscapes were formed as moraines and outwash deposits during the Saale and Weichsel glaciations and transformed though post-glacial coastal uplift and inland freshwater erosion. When considered at a general level this means that regional and national-scale patterns of soil types in Denmark tend to correlate with landscape-genetic types. Most organic and peaty post-glacial soils in Denmark are located either in river valleys, on coastal salt marshes or on reclaimed land. Similarly, most sandy and gravelly areas are located on outwash plains, while predominantly loamy soils are usually found in areas where the topsoil is the result of moraine deposits. As a consequence, the fact that there is an overrepresentation of hunting areas located on organic and sandy soils (Table 3) can be interpreted as an indication that most hunting areas are located in three types of landscape settings: Either in river valleys, on coastal salt marshes or on outwash plains. A comparison with Figure 4, which shows the geographical location of the hunting areas, highlights this 


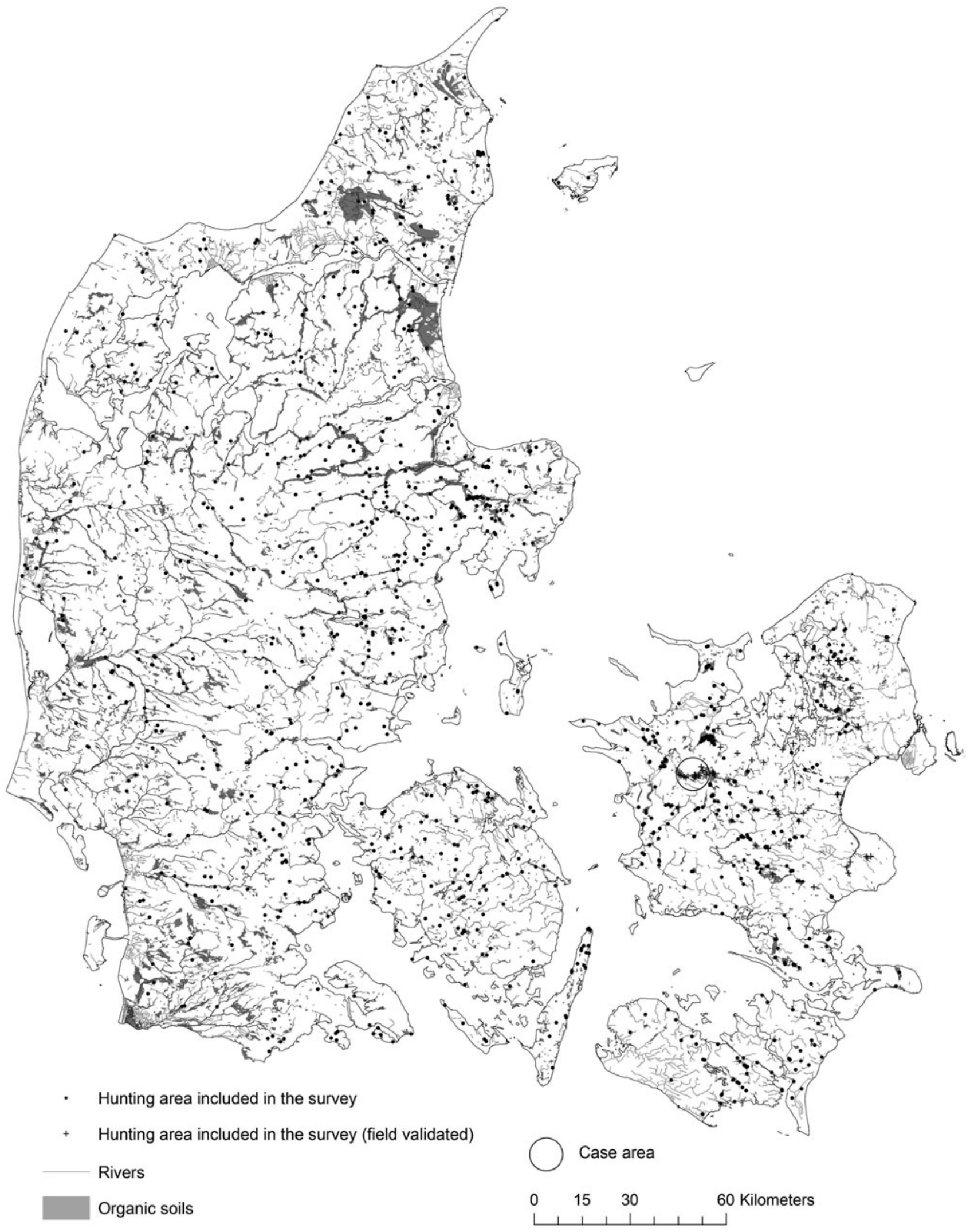

Figure 4. The location of the hunting areas in 2006. 
Table 3. The amount of hunting areas in 2006, distributed according to the soil type present at the centrepoint of each hunting structure. The percentages given are percentages of the total number of areas $(n=1061)$. The table illustrates the fact that in 2006, hunting areas were typically located on organic and sandy soils, i.e. on soil types which are relatively more difficult and expensive to use for monofunctional agriculture such as grazing and crop production. A comparison with the distribution of soil types in Denmark shows a marked overrepresentation of humus soils and an underrepresentation of clay soils among the hunting areas, Unkown soils cover special soil types (such as limerich soils) but also forest, urban zones and lakes, comprising $20 \%$ of the total area. The comparison with the distribution of soils in Denmark (according to Madsen et al., 1992) should be taken with some caution since it is based on the assumption that the percentage of the total number of areas dominated by a soil type expresses the percentage area of the soil type within the total area. Based on digital soil data from the Danish Faculty of Soil Sciences, Aarhus University (DJF, 1979) and Madsen et al. (1992) table 7a.

\begin{tabular}{llrrr}
\hline & & \multicolumn{3}{c}{ Hunting } \\
& & \multicolumn{2}{c}{ areas } & \\
\cline { 3 - 4 } Soil type & & \multicolumn{1}{c}{$n$} & Total DK (\%) \\
\hline Organic soils & Humus & 343 & 32.3 & 5.5 \\
& Total & 343 & 32.3 & 5.5 \\
Sandy soils & Coarse sand & 142 & 13.4 & 19.0 \\
& Fine sand & 82 & 7.7 & 7.9 \\
& Sand with clay & 272 & 25.6 & 22.4 \\
& Total & 496 & 46.7 & 49.3 \\
Clay soils & Clay with sand & 152 & 14.3 & 19.6 \\
& Clay & 20 & 1.9 & 4.9 \\
& Heavy clay & 5 & 0.5 & 0.7 \\
Other soils & Total & 177 & 16.7 & 25.2 \\
& Unknown & 45 & 4.2 & 19.9 \\
Total & Total & 45 & 4.2 & 19.9 \\
& & 1061 & 100 & 99.9 \\
\hline
\end{tabular}

relationship between landscape types and hunting areas. In eastern Denmark, the hunting areas are predominantly located in river valleys (shaded grey) while the hunting areas of western Denmark tend to be located in a combination of gravelly outwash landscapes, river valleys and coastal marshes.

\subsection{A multifunctional cocktail: agricultural subsidies and hunting rental as a combined land use}

As is detailed in Table 4 below, $94 \%$ of the hunting areas were situated on land registered in the General Agricultural Register of Denmark in 2006, a register recording land eligible for subsidization in accordance with the EU CAP. In 2010, however, only 703 of the fields $(66 \%)$ were registered, and of these fields 502 were registered as rotational cropland, while 97 were registered as being with permanent grass cover, and the remaining 104 were in other types of extensive land use. These results indicate that while many hunting areas $(47 \%)$ were brought into rotational production as a con-
Table 4. Changes in subsidy eligibility between 2006 and 2010 on land used for hunting in 2006. The figures are based on data reported by land owners to the authorities in order to be eligible for CAP subsidies. In 2006, a total of 995 (94\%) of the hunting areas were reported by the land owners to be located on land which was eligible for subsidies. Due to the limited spatial resolution of the register data collected in 2006, it has not been possible to ascertain if all of these areas were registered as set asides at that time, but most of the hunting areas $(98 \%)$ were located on field blocks which included fields which were fallow. In 2010, the register data had been improved, making it possible to ascertain that a total of 502 former hunting areas $(47 \%)$ had been reconverted to rotational cropland at that time while 201 (19\%) were more extensively used (potentially still for hunting). A total of 358 hunting areas $(34 \%)$ were located on land which had been removed from the register in 2010, indicating a land use other than monofunctional agriculture. Source: The general agricultural register of Denmark (GLR).

\begin{tabular}{lrr}
\hline & $n$ & $\%$ \\
\hline The 2006 General agricultural register & & \\
Registered as agricultural land in 2006 & 995 & 93.8 \\
$\quad$ Total & 995 & 93.8 \\
Not registered in 2006 & 66 & 6.2 \\
The 2010 General agricultural register & & \\
Registered as rotational agriculture in 2010 & 502 & 47.3 \\
Registered in other categories & 201 & 18.9 \\
$\quad$ Total & 703 & 66.2 \\
Not registered in 2010 & 358 & 33.8 \\
\hline
\end{tabular}

sequence of the changes in the rules for set asides in $2007 / 2008$ and the fear of losing fallow land through article 3 protection, some farmers did not comply with the intention of the policy-makers and did not return the land to subsidized monofunctional agricultural production: $19 \%$ of the areas were kept in extensive land use and $34 \%$ of the hunting areas were taken out of the subsidy regime altogether and the land was removed from the general agricultural register.

Figure 5 summarizes the observed relationship between average hunting rental prices in the (former) Danish counties and the density of observed hunting areas. A weak linear relationship can be identified between the average hunting rental prices and the density of hunting landscapes in 2006. A marked grouping and regionalization of the counties according to both levels of average hunting rents and hunting densities can be observed:

(a) The eastern urbanized counties, which in general are rich in manorial holdings, comprising the former counties of (in order of increasing hunting rent, and number of fields with hunting structures per $\mathrm{km}^{2}$ shown in bracket): Århus $(0,037)$, Bornholm $(0,023)$, Frederiksborg $(0,037)$, Storstrøm $(0,030)$, Fyn $(0,029)$ and Vestsjælland $(0,061)$.

(b) The western agriculturally dominated counties (in order of decreasing hunting rent): Vejle $(0,024)$, 


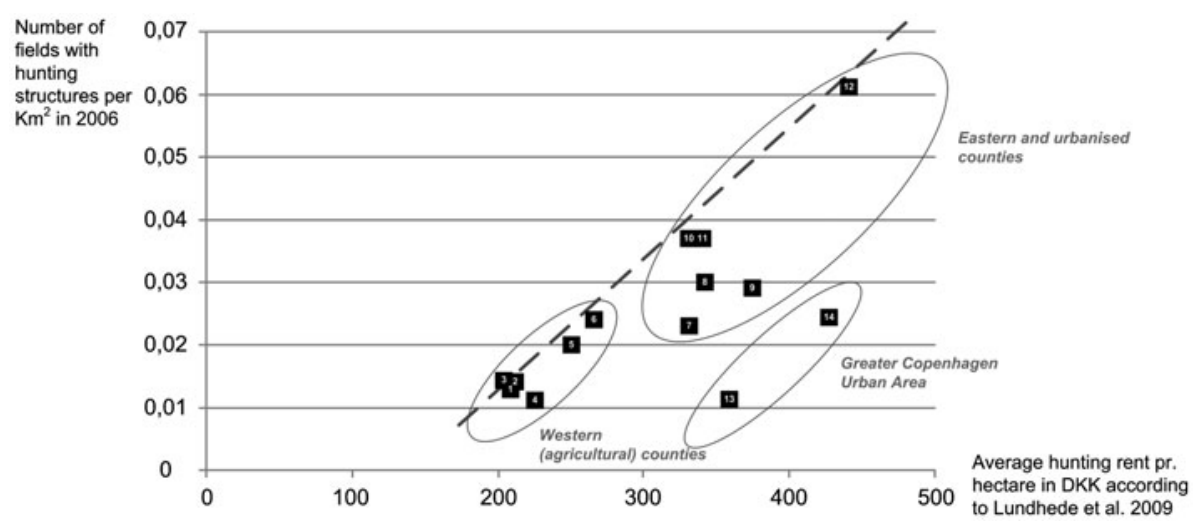

Figure 5. The relationship between hunting rental prices and the density of hunting areas in Danish counties in 2006. Correlation coefficient: 0.697 . The names of the counties are: $1=$ Viborg amt, $2=$ Ringkøbing amt, $3=$ Sønderjyllands Amt, $4=$ Ribe amt, $5=$ Nordjyllands amt, $6=$ Vejle amt, $7=$ Bornholms amt, $8=$ Storstrøms amt, $9=$ Fyns amt, $10=$ Århus amt, $11=$ Frederiksborg amt, $12=$ Vestsjællands amt, $13=$ Københavns amt and $14=$ Roskilde amt. There is a visible difference between the agricultural western Danish counties and the urbanized east Danish counties including the greater Copenhagen area. The dashed line represents a hypothized relationship between the density of hunting areas and the average hunting rent in the counties. Given the fact that there are only 14 data points (counties) in the plot, it is debateable whether a linear relationship between the two variables can be said to exist, although there is a tendency for counties with high levels of hunting rent to also have high densities of hunting areas. Data on hunting rental prices have been sourced from Lundhede et al. (2009).

Nordjylland $(0,020)$, Ribe $(0,011)$, Sønderjylland $(0,013)$ and Viborg $(0,013)$.

(c) The greater Copenhagen Urban area with the counties of Copenhagen $(0,011)$ and Roskilde $(0,024)$, obviously with relatively high hunting rents, but also with clear restrictions on the possibilities to realize the potentials due to the dense urbanization.

\section{Discussion: the land use policy context of countryside hunting - land sharing or land sparing?}

Countryside hunting constitutes a land use which is directly dependent on landscape resources available locally such as vegetation patches, earthen dikes, ditches, grassland areas, watering holes and other small biotopes integrated within the agricultural landscape matrix of monocultural production surfaces. As such, the availability of game species at levels relevant for hunting is a good example of the kind of ecosystem services which can be further enhanced and become increasingly profitable to local land owners and communities if a land sharing-oriented agricultural policy is implemented in the future. In this sense, hunting is a benefit provided as a consequence of current land sharing policies and practices in Denmark. In contrast to the Danish situation, the regions of the world where a land sparing policy has been vigorously implemented are characterized by a division between areas dominated by intensive agriculture, horticulture, plantation silviculture and viticulture on the one hand, and "wasteland" areas, national park areas and other conservation estate areas on the other. In such landscapes, which are widespread especially in the former European colonies (with the United States, Australia and New Zealand being prime examples), hunting, nature conservation practices and recreational activities dependent on public access rights typically take place outside areas with other land uses, and hunting thus depend on ecosystem services provided by the wilderness and conservation areas alone (Wheen, 2002; Christensen, 2013). In comparison to the situation in for example New Zealand, where hunting of wildlife is generally unavailable on intensively used farmland, Danish conditions for wildlife in the agricultural landscape represent a common benefit for farmers, their relatives and more or less organized recreational hunters, who are able to profit individually from the extended resource base provided as a consequence of the varied and easily accessible biotope structure embedded in the landscape. The versatile landscape regulation based on the principle of land sharing, which has permeated the transformation of the European agricultural policy from commoditybased subsidy policies to policies centred on an efficient provision of ecosystem services from agricultural land (European Commission, 2010), is an example of policy measures directly suited to support such landscape resources in the future. The original proposal for the reform of the CAP after 2013, which has been compromised into the present political agreement on the reform reached on 26 June 2013 (European Commission, 2013), dedicated $30 \%$ of direct payments to 'greening', based on the mandatory principles of crop diversification, maintenance of permanent pasture and establishment of $7 \%$ of farmland as 'ecological focus areas' (European Commission, 2011). These principles have been for- 
warded with an explicit reference to the needs for 'proper economic incentives for farmers to optimize the delivery of ecosystem services', since 'the market has failed to $[\ldots]$ reward farmers for protecting the environment and other public goods' (European Parliament, 2010). This is however not a straightforward process of transition. Especially the 'holistic' requirements for the management of multifunctional land use related to ecosystem services and the need to linking them to human well-being in cultural landscapes represent difficult cross-disciplinary challenges (Fish, 2011; Schaich et al., 2010). Possible key ecosystem service properties relevant for the future CAP comprises contributions to human well-being, services inadequately valued by markets, trade-offs between services (service bundles), site specificity (regionalizing payments), generation at different spatial and time scales and adaptation to uncertainly and sensitivity to cross-sectorial policies (Plieninger et al., 2012).

Multifunctional hunting landscapes, such as those identified and described in the present article, are examples of a landscape type which a reform of this type may foster. Hunting has always been an important rural land use in Denmark, but multifunctional hunting landscapes, where hunting functions in combination with subsidy income generation, habitat improvement and nutrient filtering replace agriculture over longer time spans on land that was previously sown with crops, only became widespread during the period when the fallow land scheme was in place allowing farmers to profit in a combination of ways from the type of landscape management on which countryside hunting depends. The fact that this happened demonstrates a willingness among Danish farmers to participate in continued investment in a wider range of ecosystem services on the part of their land which is least suited for traditional monofunctional agriculture. And it reveals that farmers are aware of the value of small biotopes and extensively used grassland and shrubland for gamekeeping purposes and capable of shifting from singularly agriculturally focused to more mixed landscape management practices, if subsidies in support of such changes are available on equal terms with those made available as a consequence of crop production.

\section{Conclusion}

The development of hunting landscapes from 1992 to 2012 demonstrates that Danish farmers and other rural landscape managers are able and willing to develop alternative non-agricultural uses of agricultural land on marginal soils in wetland areas and on fast draining gravel soils. The blooming and disappearence of the hunting landscapes coincides with changes in the CAP set aside scheme and the hunting landscapes originated as a solu- tion for farmers in need of an income from land which was not in rotation. They developed primarily in tilled valley bottoms, in western Denmark mostly on sandy soils and on the eastern islands on organic soils. The CAP subsidies seem to have supported a status quo situation of agricultural production on marginal soils up until the establishment of the fallow land scheme in 1992. From that time onwards, the policy regime indirectly came to support a change in the land use system because farmers were empowered to adapt their land use strategies while receiving subsidies. When seen in this light, the results of the present survey indicate that Danish land owners are willing to shift from a focus on agricultural production to a focus on nature conservation, given that the latter provides a competitive amount of income and does not render land ownership rights useless in the long run. The additional environmental and biodiversity advantages of the studied multifunctional agricultural hunting landscapes are underlined by their localization in wetlands along watercourses having a marked potential for wildlife as well as filtering functions related to nutrient and pesticide leaching. Although $47 \%$ of the registered hunting areas from 2006 were converted into rotational land in 2010, thus following the intention of the abolition of the set aside scheme, another $34 \%$ reacted by removing the land from the general agricultural register. The data indicate that this land sparing strategy is related not to a process of land abandonment, but rather to the establishment of more permanent types of land use, such as economically efficient hunting landscapes. Both agriculture and countryside hunting depends on and influences the density and pattern of the mostly man-made small biotopes in agricultural landscapes. National-scale monitoring has been lacking since 2001, from which time only case study surveys have been conducted, making it difficult both to link observed local landscape changes to national-scale patterns and to link such changes to the land use practices and motivations with which they are associated. There is a need for further surveys of the development in number and size of small biotopes in the danish countryside as well as information on changes in their functions, e.g. related to hunting interests. As the present paper demonstrates, further and larger-scale fieldwork efforts which combine interview methods with landscape inventory maps are needed to link social processes with biophysical changes in the danish countryside. Such surveys are likely to be the only way to establish a more comprehensive understanding of the functions associated with new as well as old biotopes in the landscape (Brandt et al., 2002; Brandt et al., 2003).

\section{References}

Antrop, M., Brandt, J., Loupa-Ramos, I., Padoa-Schioppa, E., Porter, J., Van Eetvelde, V., \& Pinto-Correia, T. (2013). How landscape ecology can promote the development of sustainable landscapes in Europe: The role of the European 
Association for Landscape Ecology (IALE-Europe) in the twenty-first century. Landscape Ecology, 28, 1641-1647.

Asferg, T. (1991). Vildtudbyttestatistik 1988/89 [Hunting statistics 1988/89]. Rønde: Afdeling for Flora- og Faunaøkologi, Danmarks Miljøundersøgelser.

Asferg, T., Olesen, C. R., Kahlert, J., Odderskær, P., \& Berthelsen, J. P. (2009). Trange tider for markernes småvildt [Hard times for the small game of the open countryside]. In $\mathrm{N}$. Kamstrup, T. Asferg, M. Flinterup, B. J. Thorsen, \& T. S. Jensen (Eds.), Vildt og Landskab - Resultatet af 6 års integreret forskning $i$ Danmark 2003-200 [Game animals and the landscape - The results of 6 years of integrated research in Denmark] (pp. 10-15). Copenhagen: The Danish Nature Agency.

Bertelsen, J. P., Ejrnæs, R., Hald, A. B., Odderskær, M. S., \& Topping, C. (2008). Fup og fakta om brak og natur [Facts and fiction about set asides and nature]. Aktuel naturvidenskab, 1, 32-34.

Bloch-Pedersen, M., Brandt, J., \& Olsen, M. (2006). Integration of European habitat monitoring based on plant life form composition as an indicator of environmental change and change in biodiversity. Danish Journal of Geography, 106, 41-54.

Brandt, J. (1994). Småbiotopernes udvikling i 1980erne og deres fremtidige status i det åbne land [The development of small biotopes during the 1980s and their future status in the countryside]. In J. Brandt \& J. Primdahl (Eds.), Marginaljorder og landskabet - marginaliseringsdebatten 10 ar efter [Marginal lands and the debate on marginalization 10 years after]. (6th ed., Vol. 6, pp. 21-49). København: FSF. Forskningsserien. Nr. 6.

Brandt, J. (2012). Godsdriften som model for det intensivt udnyttede landbrugslandskab [The management of manorial estates as a model for intensively used agricultural landscapes]. Paper presented at the Naturen i det intensivt udnyttede agerland. Dansk Landskabsøkologisk Forenings 20. Årsmøde [Nature in the intensively used agricultural landscape. The 20th annual conference of the Danish Association for Landscape Ecology]., København.

Brandt, J., Blust, G. d., \& Wascher, D. (2003). Monitoring multifunctional terrestrial landscapes. In J. Brandt \& H. Vejre (Eds.), Multifunctional landscapes. Vol. II: Monitoring, diversity and management (Vol. 2, pp. 75-86). Southampton: WIT Press.

Brandt, J., Bunce, R. G. H., Howard, D. C., \& Petit, S. (2002). General principles of monitoring land cover change based on two case studies in Britain and Denmark. Landscape and Urban Planning, 62, 37-51.

Brandt, J., Holmes, E., \& Agger, P. (2001). Integrated monitoring on a landscape scale - lessons from Denmark. In G. Groom \& T. Reed (Eds.), Strategic landscape monitoring for the Nordic countries (Vol. 523, pp. 31-41). Copenhagen: Nordic Council of Ministers.

Brandt, J., Holmes, E. W., \& Larsen, D. (1994). Monitoring 'small biotopes'. In F. Klijn (Ed.), Ecosystem classification for environmental management (pp. 251-274). Dordrecht: Kluwer Academic Publishers.

Christensen, A. Aa. (2013). Mastering the land: Mapping and metrologies in Aotearoa New Zealand. In E. Pawson \& T. Brooking, Making a new land: Environmental histories of New Zealand (2nd ed.). (pp. 310-327). Dunedin: Otago University Press.

Christensen, A. Aa., Kristensen, L. S., \& Primdahl, J. (2012a): Landbrugsundersøgelse for området Flyndersø - Sønder Lem Vig, Skive kommune [Agricultural survey of the Flyndersø- Sønder Lem Vig Area, Skive Municipality] (Ar- bejdsrapport nr. 154). Frederiksberg: Skov \& Landskab, Copenhagen University.

Christensen, A. Aa., Kristensen, L. S., \& Primdahl, J. (2012b): Landbrugsundersøgelse for Karby sogn, Morsø kommune [Agricultural survey of Karby Parish, Morsø Municipality] (Arbejdsrapport nr. 155). Frederiksberg: Skov \& Landskab, Copenhagen University.

Christensen, A. Aa., Svennningsen, S. R., \& Brandt, J. (2011). Agroparks - The European landscape convention and a European way to regional sustainable landscape development through land use integration. In Jones, B. \& Fu, B. Proceedings: The 8th world congress of the international association for landscape ecology: Landscape ecology for sustainable environment and culture (pp. 91-92). International assocation for landscape ecology, Beijing, China.

Det Jordbrugsvidenskabelige Fakultet, Aarhus Universitet (DJF). (1979). Den landsomfattende jordklassificering. Retrieved September 1, 2013, from http://www.djfgeodata.dk/datasaml/jord2.html

Det Jordbrugsvidenskabelige Fakultet, Aarhus Universitet (DJF), Fødevareøkonomisk Institut, Københavns Universitet (FOI), \& Danmarks Miljøundersøgelser, Aarhus Universitet (DMU). (2007a). Notat vedrørende konsekvenserne $i$ 2007/2008 af udtagningsforpligtelsens bortfald [Memorandum about the consequences in 2007/2008 of the removal of mandatory set asides]. Copenhagen: Memorandum ordered by the Ministry of Food, Agriculture and Fisheries and the Ministry for the Environment.

Det Jordbrugsvidenskabelige Fakultet, Aarhus Universitet (DJF), Fødevareøkonomisk Institut, Københavns Universitet (FOI), \& Danmarks Miljøundersøgelser, Aarhus Universitet (DMU). (2007b). Notat vedrørende effekterne af en permanent nulstilling af udtagningsforpligtelsen [Memorandum about the effects of a permanent removal of mandatory set asides]. Copenhagen: Memorandum ordered by the Ministry of Food, Agriculture and Fisheries and the Ministry for the Environment.

European Commission. (2010). The CAP towards 2020: Meeting the food, natural resources and territorial challenges of the future. 672, final. Brussels: European Commission.

European Commission. (2011). Proposal for a regulation of the European Parliament and tof the Council establishing rurles for direct payments to farmers under support schemes within the framework of the common agricultural policy. 625, final/2. Brussels: European Commission.

European Commission. (2013). Political agreement on the CAP reform. Retrieved July 1, 2013, from http://ec.europa.eu/ agriculture/cap-post-2013/agreement/index_en.htm

European Parliament. (2010). Resolution of 8 July 2010 on the future of the Common Agricultural Policy after 2013. File 2009/2236 (INI). Strasbourg: European Parliament.

Fish, R. D. (2011). Environmental decision making and an ecosystems approach: Some challenges from the perspective of social science. Progress in Physical Geography, 35, 671-680.

Hansen, H. P. (2000). Jagt i Danmark år 2000 [Hunting in Denmark in the year 2000] (2 Vols.) (Master thesis). University of Roskilde, Denmark.

Hedegaard, F., Holter, T., Jønson, C., Pierri, S., \& Riberholt, L. (1995). Jagt på småbiotoper [Hunting at small biotopes]. Geografi, 1.modul, [Geography 1st. module project]. Roskilde: University of Roskilde.

Hirsch, E. (1985). Dessau-Wörlitz - Aufklärung und Frühklassik [Dessau-Wörlitz - Enlightenment and early classical]. Leipzig: Koehler \& Amelang. 
Hodge, I. (2007). Presidential address: The governance of rural land in a liberalised world. Journal of Agricultural Economics, 38, 409-432.

Jensen, K. M., \& Jensen, R. H. (1977). En landbrugsgeografisk analyse af Gadbjerg og Givskud sogne [An agriculturalgeographical analysis of the Parishes of Gadbjerg and Givskud]. Danish Journal of Geography, 76, 34-51.

Jensen, K. M., \& Reenberg, A. (1980). Dansk landbrug. udvikling $i$ produktion og kulturlandskab [Danish agriculture. Developments in production and the cultural landscape]. Laboratorium for kulturøkologi og landbrugsgeografi, Kobenhavns universitet.

Kristensen, I. T., \& Pedersen, B. F. (2008). Intern Rapport Braklagte og udyrkede arealer 2007 og 2008 [Internal report - set asides and areas without crops in 2007 and 2008]. In DJF Markbrug, 19. Tjele and Aarhus: Det jordbrugsvidenskabelige fakultet, Aarhus Universitet.

Kristensen, S. B. P., Reenberg, A., \& Pena, J. J. D. (2009). Exploring local rural landscape changes in Denmark: A human-environmental timeline perspective. Geografisk Tidsskrift-Danish Journal of Geography, 109, 47-67.

Levin, G., \& Jepsen, M. R. (2010). Abolition of set-aside schemes, associated impacts on habitat structure and modelling of potential effects of cross-farm regulation. Ecological Modelling, 221, 2728-2737.

Lundhede, T. H., Jacobsen, J. B., \& Thorsen, B. J. (2009). Hvad bestemmer jagtlejen? [What defines the hunting rent?] In N. Kamstrup, T. Asferg, M. Flinterup, B. J. Thorsen, \& T. S. Jensen (Eds.), Vildt og Landskab - Resultatet af 6 års integreret forskning i Danmark 2003-2008 [Game animals and the landscape - The results of 6 years of integrated research in Denmark] (pp. 50-53). Copenhagen: The Danish Nature Agency.

Madsen, H. B. H., Nørr, A. H. \& Holst, K. A. (1992). Atlas over Danmark. Den danske jordklassificering [Atlas of Denmark. The Danish soil classification] (Serie I, Bind 3). København: C.A. Reitzel.

Ministry of the Environment. (2013). Lov om Naturbeskyttelse (Lovbekendtgørelse nr. 951 af 3/7 2013). Retrieved July 2013, from www.retsinformation.dk.

Mogensen, B., Berthelsen, J. P., Hald, A. B., Hansen, K., Jeppesen, J. L., Odderskær, P., ... Krogh, P. H. (1997). Livsbetingelser for vilde flora of fauna på braklagte arealer - En litteraturudredning [The conditions for wild flora and fauna on set aside land - A literature review]. Roskilde: Miljø- og Energiministeriet, Danmarks Miljøundersøgelser.

Olesen, C. R., Asferg, T., \& Forchhammer, M. C. (2002). Rådyret - fra fåtallig til almindelig [The roe deer - from rare to ordinary]. National Environmental Research Agency, The Ministry for the Environment, Copenhagen.

Pedersen, S. E. (1980). Danske herregårde: Bygninger, haver, landskaber [Danish Manorial estates: Buildings, gardens and landscapes]. København: Selskabet for bygnings- og landskabskultur.

Pedersen, J. L. (2011). Jagtens indflydelse på landskabet - Jagt som encitament til landskabsforbedringer [The influence of hunting on the landscape - Hunting as a motivation for landscape improvements] (Master thesis). University of Copenhagen, Denmark.

Persson, R. (1981). Jakt och jägara. Initiering och utövandemönster. En kortlägning af jakten och jägarna i Skåne [Hunting and hunters. Motivations and practices. A mapping of hunting and hunters in Skåne]. Lund: Lunds Universitet.

Phalan, B., Onial, M., Balmford, A., \& Green, R. E. (2011). Reconciling food production and biodiversity conservation: Land sharing and land sparing compared. Science, 333, 1289-1291.

Plieninger, T., Hochtl, F., \& Spek, T. (2006). Traditional landuse and nature conservation in European rural landscapes. Environmental Science \& Policy, 9, 317-321.

Plieninger, T., Schleyer, C., Schaich, H., Ohnesorge, B., Gerdes, H., Hernandez-Morcillo, M., \& Bieling, C. (2012). Mainstreaming ecosystem services through reformed European agricultural policies. Conservation Letters, 5, 281-288.

Primdahl, J., Bojesen, M., Vesterager, J. P., \& Kristensen, L. S. (2012). Hunting and landscape in Denmark: Farmers' management of hunting rights and landscape changes. Landscape Research, 37, 659-672.

Reenberg, A. (2009). Land system science: Handling complex series of natural and socio-economic processes. Journal of Land Use Science, 4(1-2), 1-4.

Schaich, H., Bieling, C., \& Plieninger, T. (2010). Linking ecosystem services with cultural landscape research. Gaia-ecological Perspectives for Science and Society, 19, 269-277.

Statistics Denmark. (2012). Statbank Denmark BDF307: Employment in agriculture, by county, unit, type and working time. Copenhagen: Statistics Denmark.

Tscharntke, T., Clough, Y., Wanger, T. C., Jackson, L., Motzke, I., Perfecto, I., ... Whitbread, A. (2012). Global food security, biodiversity conservation and the future of agricultural intensification. Biological Conservation, 151, 53-59.

Vejre, H., Abildtrup, J., Kaergaard, N., Fritzboger, B., Busck, A. G., \& Olsen, S. B. (2012). Revitalisation of common use in management of modern multifunctional landscapes. Landscape Research, 37, 637-657.

Vreeker, R., Groot, H. L. F. d., \& Verhoef, E. T. (2004). Urban multifunctional land use: Theoretical and empirical insights on economies of scale, scope and diversity. Built Environment, 30, 289-307.

Wheen, N. (2002). A history of New Zealand environmental law. In E. Pawson \& T. Brooking (Eds.), Environmental histories of New Zealand (pp. 262-274). Melbourne: Oxford University Press.

Wilson, G. A. (2001). From productivism to post-productivism - and back again? Exploring the (un)changed natural and mental landscapes of European agriculture. Tranactions of the Institute of British Geographers, New Series, 26, 77-102. 